\title{
Age-Related Association of Insulin-Dependent Diabetes Mellitus with BfF1 and the HLA-B18, BfF1 Haplotype
}

\author{
J. Bertrams ${ }^{1}$, M. P. Baur ${ }^{2}$, D. Grüneklee ${ }^{3}$ and F. A. Gries ${ }^{3}$ \\ ${ }^{1}$ Department of Laboratory Medicine, St. Elisabeth Hospital, Essen \\ ${ }^{2}$ Institute of Medical Statistics, Documentation and Data Processing, University of Bonn, and \\ ${ }^{3}$ Diabetes Research Institute, University of Diisseldorf, Federal Republic of Germany
}

Summary. Five hundred and ninety-nine patients with insulin-dependent (Type 1) diabetes mellitus were typed for $\mathrm{Bf}$ (factor B) polymorphism, and 318 of them for HLA-A, B and C antigens. Bf and HLA antigen frequencies were compared with those in 536 normal controls. A significant positive association between Type 1 diabetes and the rare factor $\mathrm{B}$ variant $\mathrm{BfF} 1$ was found $\left(p<10^{-3}\right)$, but this was present only in patients aged under 16 years at onset of the disease $(p<0.005)$. There was a strongly positive linkage disequilibrium between BfF1 and HLA-B18 in the diabetic patients. This, too was especially pronounced in the juvenile onset cases, in whom it was significantly stronger than in controls $\left(p<10^{-3}\right)$. The known positive associations between Type 1 diabetes and HLA-B8, $-\mathrm{B} 15$ and - $\mathrm{Cw} 3$ were confirmed.

Key words: Insulin-dependent (Type 1) diabetes, HLA-B18, BfF1, linkage disequilibrium

Insulin-dependent (Type 1) diabetes mellitus shows a significant positive association not only with HLADw3/DR3 and HLA-Dw4/DR4 [1, 2] but also with $\mathrm{BfF} 1$, a rare gene product of the properdin factor $\mathrm{B}$ system which is linked to HLA [3,4]. In this study a group of patients with Type 1 diabetes mellitus was typed for HLA-A, B, C antigens and Bf phenotypers. The HLA and $\mathrm{Bf}$ associations with Type 1 diabetes and the linkage disequilibrium between HLA-B18 and $B f F 1$ were investigated in relation to age at onset of disease.

\section{Material and Methods}

599 Caucasoid patients with Type 1 diabetes mellitus were typed for Bf polymorphism and 318 of them also for the HLA-A, B, C antigens.
The following HLA-antigens could be defined, using the standard micro-lymphocytotoxicity test [5]: HLA-A1, A2, A3, Aw23, Aw24, A25, A26, A28, A29, Aw30, Aw31, Aw32, Aw33; B5, B7, B8, B13, B14, B18, B27, Bw35, B37, Bw38, Bw39, Bw40, Bw41, Bw44, Bw45, Bw47, Bw49, Bw50, Bw53, Bw55, Bw56, Bw57, Bw58, Bw60, Bw61, Bw62, Bw63, Cw1, Cw2, Cw3, Cw4, Cw5. Bf polymorphism (BfS, F, S0.7, F1) was analysed by thin layer high voltage agarose electrophoresis and subsequent immunofixation with $\mathrm{Bf}$ antisera (Behring-Werke) as described by Alper et al. [3] and Reuter and Hoffman [7]. All BfF1 and BfS0.7 results were corroborated by typing relatives.

Table 1. HLA and Bf phenotype frequencies, BfF1, B18 baplotype frequency (hf) and its gametic association (delta value) in patients with Type 1 diabetes and normal controls. (If there is no association between two genes at two linked loci, they are in linkage equilibrium, and the frequency of their occurrence together (= haplotype frequency) must be the product of the gene frequencies. If the two genes are positively or negatively associated, they are in linkage disequilibrium, the haplotype frequency deviates from the expected gene product and the deviation is expressed by the so-called linkage disequilibrium parameter or delta value.)

\begin{tabular}{cccl}
\hline & Patients & Controls $^{\mathrm{a}}$ & $p$ value $^{\mathrm{b}}$ \\
\hline HLA & $n=318$ & $n=536$ & \\
-B7 & $57(18 \%)$ & $118(22 \%)$ & NS \\
-B8 & $119(37 \%)$ & $89(18 \%)$ & $<10^{-5}$ \\
-B15 & $79(25 \%)$ & $69(13 \%)$ & $<10^{-5}$ \\
- B18 & $48(15 \%)$ & $62(12 \%)$ & NS \\
-Cw3 & $97(31 \%)$ & $117(22 \%)$ & $<0.01$ \\
Bf & $n=599$ & $n=536$ & \\
F & $156(26 \%)$ & $143(27 \%)$ & NS \\
S & $554(93 \%)$ & $513(96 \%)$ & $<0.05$ \\
F1 & $36(6 \%)$ & $10(2 \%)$ & $=10^{-3}$ \\
S0.7 & $18(3 \%)$ & $11(2 \%)$ & NS \\
hf (BfF1, B18): & 0.0270 & 0.0044 & \\
Delta value (BfF1, B18): & & \\
Absolute: & 0.0244 & 0.0038 & $=3 \times 10^{-5}$ \\
Relative: & 0.8250 & 0.4368 & $=3$ \\
\hline
\end{tabular}

a Bertrams and Baur [6]

$b$ uncorrected

$\mathrm{NS}=$ not significant 
Table 2. Age relationship of HLA and Bf frequencies and BfF1, B18 linkage disequilibrium (delta value) in patients with Type 1 diabetes mellitus and normal control subjects

\begin{tabular}{|c|c|c|c|c|c|c|c|}
\hline \multirow[b]{2}{*}{$\begin{array}{l}\text { Age at onset } \\
\text { of disease } \\
\text { (years) }\end{array}$} & \multicolumn{3}{|c|}{ No of patients $(\%)$} & \multirow{2}{*}{$\begin{array}{l}\text { No of } \\
\text { controls } \\
(\%) \\
\text { d } \\
(n=536)\end{array}$} & \multicolumn{3}{|c|}{ Significance } \\
\hline & $\begin{array}{l}\mathrm{a} \\
(0-10) \\
(n=128)\end{array}$ & $\begin{array}{l}\mathrm{b} \\
(11-15) \\
(n=136)\end{array}$ & $\begin{array}{l}\mathrm{c} \\
(16-29) \\
(n=54)\end{array}$ & & \multicolumn{2}{|c|}{$\begin{array}{l}\text { Comparison } \\
\text { between }\end{array}$} & $p$ \\
\hline HLA-B7 & $15(12 \%)$ & $32(24 \%)$ & $10(19 \%)$ & $118(22 \%)$ & a & $\mathrm{b}+\mathrm{c}$ & $<0.05$ \\
\hline$-\mathrm{B} 8$ & $42(33 \%)$ & $56(41 \%)$ & $21(39 \%)$ & $99(18 \%)$ & & & \\
\hline$-\mathrm{B} 15$ & $41(32 \%)$ & $29(21 \%)$ & $9(17 \%)$ & $69(13 \%)$ & $\mathbf{a}$ & $b+c$ & $<0.025$ \\
\hline$-\mathrm{B} 18$ & $19(15 \%)$ & $20(15 \%)$ & $8(15 \%)$ & $62(12 \%)$ & & & \\
\hline$-\mathrm{Cw} 3$ & $47(37 \%)$ & $37(27 \%)$ & $13(24 \%)$ & $117(22 \%)$ & & & \\
\hline BfF1 & $10(8 \%)$ & $9(7 \%)$ & $1(2 \%)$ & $10(2 \%)$ & $\begin{array}{l}\mathrm{a} \\
\mathrm{b}\end{array}$ & $\begin{array}{l}\mathrm{d} \\
\mathrm{d}\end{array}$ & $\begin{array}{l}<0.005 \\
<0.005\end{array}$ \\
\hline \multicolumn{8}{|c|}{ Delta value (BfF1, B18): } \\
\hline Relative: & 0.8839 & 0.7424 & 0.1002 & 0.4368 & $\begin{array}{l}a \\
b\end{array}$ & $\begin{array}{l}\mathrm{d} \\
\mathrm{d}\end{array}$ & $\begin{array}{l}<10^{-4} \\
<10^{-3}\end{array}$ \\
\hline
\end{tabular}

a Bertrams and Baur [6]

Bf and HLA phenotype frequencies of the patients were compared with corresponding control values [6] by chi-square tests with Yates' correction. HLA-Bf haplotype frequencies and linkage disequilibrium parameters (delta, D) were calculated by standard methods [8-10]. Relative delta values of HLA-B18, BfF1 in Type 1 diabetic patients and controls were computed according to Dausset et al. [11] and compared for significance by $2 \times 2 \times 2$ contingency tables as given in detail elsewhere [12].

\section{Results}

As expected HLA-B8, $-\mathrm{B} 15$ and -Cw3 antigen frequencies were significantly increased in the patient group. However, minor differences in frequencies of B7 (decreased) and B18 (increased) were not statistically significant (Table 1 ).

One Bf gene product showed a major deviation: the rare variant $\mathrm{BfF} 1$ was significantly increased $\left(6.0 \%\right.$ versus $\left.1.9 \%, p=10^{-3}\right)$. The frequency of BfS was slightly decreased $(92.5 \%$ versus $95,7 \%$, $p<0.05$ ), although an increase might have been expected in view of the positive linkage disequilibrium with HLA-B8 reported elsewhere.

Of the $20 \mathrm{BfF} 1$-positive patients, 17 were also positive for $\mathrm{B} 18$, indicating a strong association between the B18 and BfF1 genes $(d=0.0244)$. In normal controls the gametic association of B18 and $\mathrm{BfF} 1$ is much weaker $(d=0.0038)[6]$. An increased $\mathrm{B} 18, \mathrm{BfF} 1$ haplotype frequency was also found in the diabetics $(0.0270$ versus 0.0044 in controls $)$. For comparison of the absolute delta values the relative delta values have been calculated. The difference between the Type 1 diabetic patients and normal controls was highly significant $\left(p=3 \times 10^{-5}\right)$.

The data were also analysed in relation to the age of the patients at the time of onset of diabetes and compared with the findings in controls. As shown in Table 2, a significantly increased frequency of BfF1 was found in the patients under 11 years of age $(7.8 \%, p<0.005)$ and in those from 11 to 15 years old $(6.6 \%, p<0.005)$ but not in the age group 16 to 29 years $(1.9 \%, p>0.05)$. The strength of the gametic association between $\mathrm{B} 18$ and BfF1 genes was also age related. In comparison to the normal delta value between BfF1 and B18 $(d=0.0038)$, significantly increased linkage disequilibria were found only in the two groups of patients aged $\leqslant 15$ years $\left(0-10\right.$ years: $d=0.8839, p<10^{-4} ; 11-15$ years: $d=0.7424, p<10^{-3}$ ), while patients older than 15 years showed only a very weak positive gametic association of $\mathrm{BfF} 1$ and $\mathrm{B} 18(d=0.1002)$ which is even weaker than in normal controls $(d=$ 0.4368 ). The HLA antigen frequencies were also analysed in relation to the age of the patients at the onset of diabetes (Table 2). The frequency of B18 was almost identical in all three age groups and only slightly increased relative to controls. The youngest patients ( $0-10$ years) showed the highest frequency of B15 and the lowest of B7, these differences from older patients being statistically significant (Table 2).

\section{Discussion}

There are three significant findings of this study: the increased frequency of the rare properdin factor B allele $B f F 1$, the very strong linkage disequilibrium between BfF1 and the B18 genes, and the age relationship of the BfF1 association with diabetes as well as of the strength of this gametic association. 
Increased BfF1 frequency in Type 1 diabetic patients was first reported independently by Bertrams et al. [12] and by Alper (Third Workshop on the Genetics of the Complement System 1979; see also [13]), and was confirmed by others [14-18]. The great differences in the strength of the association reported by different authors can be explained by its strong age relationship $[15,18,19]$.

Another result of our study is the pronounced increase of B15 in the youngest patients ( $0-10$ years) and the trend of a decreasing frequency of B15 in patients with later manifestation of Type 1 diabetes (11-15 and 16-29 years), as also shown by Dausset [20] and Kirk et al. [15]. The frequency of B7 was very low in the youngest age group (0-10 years). Thus Type 1 diabetes mellitus may develop early in life predominantly in $\mathrm{BfF} 1-$ and $\mathrm{B} 15$-positive and B7- negative individuals.

The most striking finding of this study is the marked linkage disequilibrium between $\mathrm{BfF} 1$ and B18 genes in Type 1 diabetes $(d=0.0244)$, which is significantly stronger than in normal controls $(d=$ 0.0038).

This very strong linkage disequilibrium is also age related and could be demonstrated only in children who were under 16 years of age at the onset of the disease.

Thus we have been able to demonstrate another HLA linkage group indicating increased susceptibility to Type 1 diabetes, namely BfF1, B18, in addition to the well known 'high risk' gene complexes HLAA1, B8, Dw3/DR3 and HLA-A2, Cw3, B15, Dw4/ DR4.

As shown by the Type 1 diabetes study of the last Histocompatibility Workshop [21] the BfF1 and B18 genes are also linked to HLA-DR3. Further studies should investigate whether the increase of BfF1 in Type 1 diabetes is secondary to the increase of HLADR3 or whether it stands for functional involvement of this rare complement variant in the pathogenesis of the disease.

Acknowlegdement. This study was supported by the Deutsche Forschungsgemeinschaft: SFB113, project B3 and B4 and grants Be 758/3/4, Ba 660/1.

\section{Reference}

1. Cudworth AG, Festenstein H (1978) HLA genetic heterogeneity in diabetes mellitus. Br Med Bull 34: 285-290

2. Cudworth AG (1978) Type I diabetes mellitus. Diabetologia 14: 281-291

3. Alper CA, Boenisch T, Watson L (1972) Genetic polymorphism in human glycine-rich beta-glycoprotein. J Exp Med 135: $68-80$

4. Allen FH Jr (1974) Linkage of HLA-A and GBG. Vox Sang 27: $382-384$
5. Terasaki PI, Parks MS (1976) Microdroplet lymphocyte cytotoxicity test. In: Ray JG, Hare DB, Pedersen PD, Mullally DI (eds) Manual of tissue typing techniques. DHEW publication No. (NIH) 76-545, pp 69-80

6. Bertrams J, Baur MP (1979) HLA-A, B, Bf three point association of 1072 haplotypes in a German population. Tissue Antigens 14: 317-324

7. Reuter W, Hoffmann B (1977) Demonstration of the polymorphism of $\mathrm{C} 3$, Tf and $\mathrm{Bf}$ in thinlayer agarose gel electrophoresis. A simple, variable and economic technique. Ärztl. Labor 23: $178-186$

8. Li CC (1961) Human genetics - principles and methods. McGraw-Hill, New York.

9. Ceppellini R, Curtoni ES, Mattiuz PL, Miggiano V, Scudeller G, Serra A (1967) Genetics of leucocyte antigens. A family study of segregation and linkage. In: Ceppellini R (ed) Histocompatibility testing 1967. Munksgaard, Copenhagen pp 149-185

10. Cavalli-Sforza LL, Bodmer WF (1971) The genetics of human populations. Freemann, San Francisco

11. Dausset J, Legrand L, Lepage V, Contu L, Mercelli-Barge A, Wildloecher I, Benjamin A, Meo T, Degos L (1978) A haplotype study of HLA complex with special reference to the HLA-DR series and to $\mathrm{Bf}, \mathrm{C} 2$ and Glyoxalase 1 polymorphisms. Tissue Antigens 12: 297-313

12. Bertrams J, Baur MP, Grüneklee D, Hintzen U (1980) Association of BfF1 and haplotype HLA-B18, BfF1 with insulin dependent diabetes mellitus. III Workshop on the genetics of the complement system, Köln, 25-27 May 1979. Immunobiology 158: $129-133$

13. Raum D, Alper CA, Stein R, Gabbay KH (1979) Genetic marker for insulin dependent diabetes mellitus. Lancet 1 : $1208-1210$

14. Bertrams J, Baur MP, Grüneklee D, Gries FA (1979) Association of BfF1, HLA-B18 and insulin-dependent diabetes mellitus. Lancet 2: 98 and 376

15. Kirk RL, Serjeantson SW, Theophilus J, Zimmet P, Whitehouse S, Court JM (1979) Age relationship between insulindependent diabetes mellitus and rare alleles of properdin factor B. Lancet 2: 537

16. Kirk RL, Theophilus J, Whitehouse S, Court J, Zimmet $P$ (1979) Genetic susceptibility to diabetes mellitus: the distribution of properdin factor $\mathrm{B}(\mathrm{Bf})$ and glyoxalase (GLO) phenotypes. Diabetes 28: 949-951

17. Kirk RL, Serjeantson SW, Theophilus J, Zimmet P, Whitehouse S, Court JM (1979) Age relationship between insulindependent diabetes mellitus and rare alleles of properdin factor B. Lancet 2: 537

18. Bernal JE, Ellis DA, Haigh J (1979) Bf in insulin-dependent diabetes mellitus. Lancet 2: 961

19. Barbosa J, Weitkamp L, Guttormsen S, Johnson S, Szalapski E $\mathrm{Jr}$ (1979) Bf in early-onset insulin-dependent diabetes. Lancet 2: $1239-1240$

20. Dausset J (1977) In: Dausset J, Svejgaard A (eds) HLA and disease. Munksgaard, Copenhagen, p 296

21. Svejgaard A, Platz P, Ryder LP (1980) Insulin-dependent diabetes mellitus. Joint results of the 8 th Workshop study. In: Terasaki PI (ed) Histocompatibility testing 1980. The Regents of the University of California pp 638-656

Received: 6 August 1979

and in revised form: 20 January 1981

Dr. Jörg Bertrams

Abteilung für Laboratoriums-Medizin

St. Elisabeth-Krankenhaus

Moltkestraße 61

D-4300 Essen 1, Federal Republic of Germany 